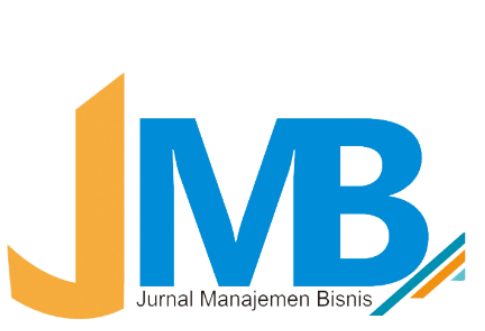

\title{
EFFECT OF WORK DISCIPLINE, LEADERSHIP STYLE AND TRAINING ON EMPLOYEE PERFORMANCE IN RSUD HAJI MAKASSAR
}

\author{
Yusrab Ardianto Sabban ${ }^{1}$, Masyadi ${ }^{2}$ \\ ${ }^{1}$ STIE Amkop, Makassar, Indonesia \\ ${ }^{2}$ STIE Lamappapoleonro, Sulawesi Selatan, Indonesia \\ Corresponding Author's Email:yusrabardianto@gmail.com
}

Received:19-07-2020 | Revision: 20-09-2020 | Accepted:28-10-2020

To cite this document:

Sabban, Yusrab Ardianto and Masyadi (2020) "Effect of Work Discipline, leadership Style and Training on Employee Performance in RSUD Haji Makassar", Manajemen Bisnis, Vol. 10, No. 02, pp.27-35, http://ejournal.umm.ac.id/index.php/jmb/article/view/10861

\section{ABSTRACT}

The purpose of this study was to analyze the effect of work discipline, leadership style, and training on device performance partially and simultaneously, and to analyze which variables had the most dominant influence on the performance of the employees of RSUD Haji Makassar. The sample of this study was 120 people, using saturated samples, with the method of multiple linear regression analysis with the help of the SPSS program. The result showed that employee performance is influenced by work discipline, leadership style and training. The variable that has the most dominant influence on the performance of employees at RSUD Haji Makassar is training. Therefore, it is recommended to allocate funds for training activities and develop an incentive policy for fostering responsibility and employee integrity.

Keywords: Work Discipline, Leadership Style, Training and Employee Performance

\section{INTRODUCTION}

As state servants and public servants, employees are required to have high performance and responsibility in providing services to the community. This is important to do to improve the image of employees who are far behind, which when traced and searched for the cause, there is a difference between the expectations and the reality received, which creates a feeling of dissatisfaction, which leads to employee performance. Performance is work performance, namely the comparison between real work results and the work standards set (Dessler, 2011). Performance is the work achieved by a person in carrying out the tasks assigned to him based on skills, experience and seriousness and time (Hasibuan, 2002). Performance is the level at which employees achieve job requirements efficiently and effectively (Simamora, 2013). Then Robbins (2014) defines performance, which is a result achieved by employees in their work according to certain 
criteria that apply to a job. According to Sastrohadiwiryo (2013), work discipline is an attitude of respect, respect, obedience and obedience to the applicable regulations, both written and unwritten and able to carry them out and not evoke sanctions if they violate their duties and authorities. Rorimpanday (2013) stated that leadership style is a comprehensive pattern of the actions of a leader, both visible and invisible to his subordinates. Leadership style describes a consistent philosophy, skills, traits and attitudes that underlie one's behavior. The leadership style will show directly about a leader's belief in the abilities of his subordinates. This means that leadership style is behavior and strategy as a result of a combination of the philosophy, skills, traits, attitudes, which are often applied by a leader when he tries to influence the performance of his subordinates.

Leadership style is defined as leadership style techniques in influencing subordinates in carrying out their duties based on the authority and power to carry out management functions (Suyanto, 2013). Leadership style is a person's behavior that can influence others and who has managerial authority. Whereas leadership is what leaders do, namely the process of leading a group and influencing the group to achieve a goal (Robbins, 2014). According to Tampubolon (2013) leadership style is behavior and strategy, as a result of a combination of philosophies, skills, traits, attitudes, which are often applied by a leader when he tries to influence the performance of his subordinates. Training has a current orientation and helps employees to achieve certain skills and abilities in order to be successful in carrying out their work. Training is every attempt to improve the performance of their responsibilities, or a job that has something to do with their job.

From the researcher's observations, there are indications found in relation to the performance of the RSUD Haji Makassar employees, including (1) employee performance is still low, (2) some employees show low discipline, as a result of lack of employee trust in their leaders, and vice versa leadership towards subordinates, (3) lack of support from leadership which causes employee morale to decrease, (4) less assertive leadership style, less involvement of employees in decision making, (5) there are still many employee complaints about uneven training participants. The percentage of employee discipline based on late arrival has increased from July to August 2020, namely from $7.33 \%$ to $7.48 \%$, so that the employee discipline rate has decreased. Meanwhile, based on the return home, it decreased from $5.04 \%$ to $2.13 \%$. Another gap is that the leadership style is less firm, the absence of strict sanctions, employee complaints about training activities that are not evenly distributed, it affects the low performance of the employees of RSUD Haji Makassar. The performance management applied by the organization has not been optimal to provide better work results for organizations that are influenced by the quality of work life. The purpose of this study was to analyze the effect of work discipline, leadership style and training on the performance of the employees of RSUD Haji Makassar, and to analyze the dominant variables affecting employee performance. 


\section{LITERATURE REVIEW}

According to Sinunungan (2012) discipline is the psychological attitude of a person or group of people who always desire to follow / obey all the rules that have been set.. Nitisemito (2013) states that discipline is an attitude, behavior and actions in accordance with company regulations, both written and unwritten. On the other hand, discipline is the awareness and willingness of a person to obey all company regulations and prevailing social norms (Aritonang, 2010). Work discipline is an attitude, behavior that is carried out voluntarily and with full awareness and conditions to follow the rules set by the company, both written and unwritten. Undisciplined behavior that arises is a reflection of employees' negative perceptions of the control exercised by their superiors. Conversely, disciplinary behavior that arises is a reflection of a positive perception of superior control. This is in line with the opinion of Buhler (2010), that discipline really plays an important role in shaping behavior. Just as rewards are effective in motivating people, discipline when used appropriately can be equally effective. Work Discipline, is a form of obedience of an employee's behavior in complying with certain provisions or regulations related to work, and is enforced in an organization. Indicators of work discipline according to Rivai (2013) are attendance, regulatory observance, adherence to working standards, high level of vigilance, ethical work.

A leader style is someone who can influence others and who has managerial authority. Meanwhile, leadership is what leaders do, namely the process of leading a group and influencing the group to achieve a goal (Robbins, 2014). Leadership style is a process for influencing others to understand and agree with what needs to be done and how the task is carried out effectively, as well as a process for facilitating individual and collective efforts to achieve common goals (Yukl, 2015). Leadership style, defined as how an employee receives, understands, is affected, and gives an assessment of the leadership of the boss. Indicators measuring the style of dreaming according to Kartini (2011) are the maturity of decision-making, motivating ability,communication maturity, subordinate control, responsibility.

Training is a program to improve the ability to carry out work individually, in groups and / or based on levels of position in an organization or company. Training is a learning process that involves the acquisition of skills, concepts, rules, or attitudes to improve work performance (Simamora, 2013). The importance of training for human resources in an organization is that human resources who occupy a certain position do not necessarily have the capabilities that meet the requirements needed in that position. This also requires organizational support and goals such as more efficient production, distribution of goods and services, reducing operating costs, improving quality, and more effective personal relationships (Mangkunegara, 2013). Training is an activity organized by an organization to improve employee performance in terms of work competency, productivity, and skills needed in a particular job. Indicators for training according to Thaif (2015) are: training instructor, training method, training time, and training benefits. 
Mathis \& Jackson (2011) state that performance is basically what employees do or don't do. Performance is the result of work behavior (Kotler \& Armstrong, 2012). According to Hasibuan (2002) performance is a result of work achieved by a person in carrying out the tasks assigned to him based on skill, experience and seriousness and time. In other words, performance is the work achieved by a person in carrying out the tasks assigned to him in accordance with the specified criteria. The three main factors that influence performance are individual (ability to work), work effort (desire to work), and organizational support (opportunity to work). Performance or performance, is the achievement or achievement of a person with respect to all tasks assigned to him. Sinambela \& Al. (2012) define employee performance as an employee's ability to perform certain skills. Employee performance is very necessary, because with this performance it will be known how far the employee's ability to carry out the tasks assigned to him. Employee performance is a skill possessed by employees in carrying out their work tasks which include engineering skills, conceptual skills, and interpersonal relationship capabilities. indicators measuring employee performance according to Dwiyanto (2014), are productivity, service quality, responsiveness, responsibility, and accountability.

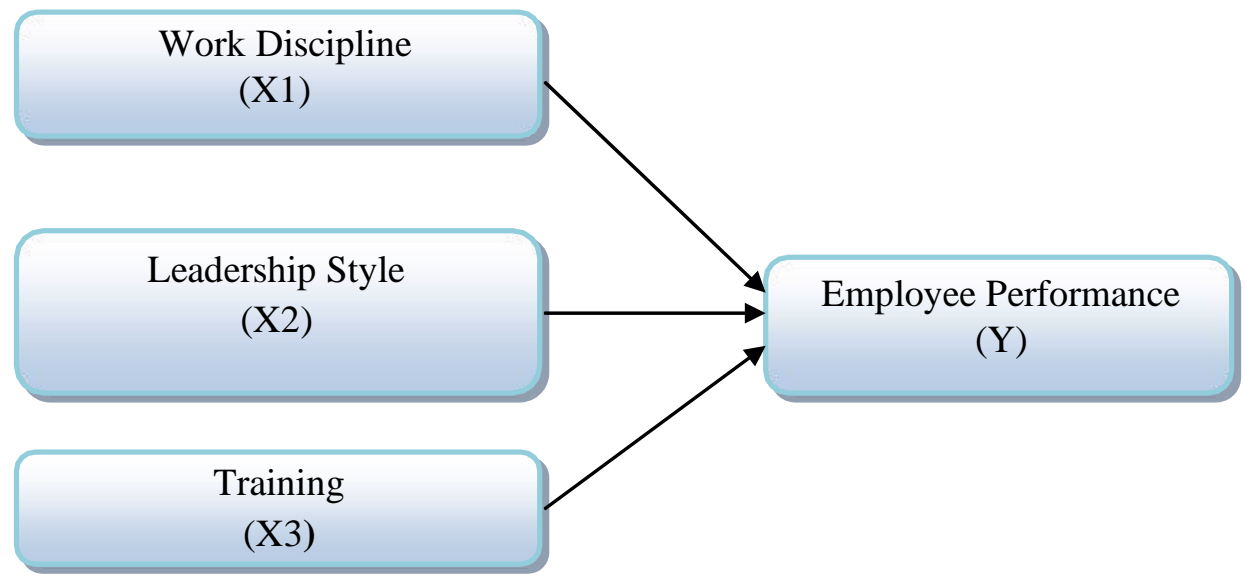

Figure 1. Conceptual Framework

\section{RESEARCH METHOD}

This research includes a type of descriptive research with a quantitative approach. According to Arikunto in Saban's Echdar (2017), descriptive research aims to portray systemmatically and accurately the facts and characters of the population or about a particular field. Quantitative research is a method that emphasizes the objective aspects of quantitative easing of social phenomena, where each social phenomenon is spelled out in several components of the problem, variabel and indicators. The study also used causal design, aimed at analyzing the relationship or level of influence of free variables on bariabel bound, whether the relationship is significant enough through regression analysis. The population of this study is all employees in the hospital totaling 596 employees. The sampling used Arikunto's opinion in Saban's Echdar (2017) if researchers had several hundred subjects in the population, they could use approximately 
25- $30 \%$ of that number. Based on this opinion, the study sample was $377 \times 27 \%=$ 101.79, rounded up 102 employees of RSUD Haji Makassar. Research site at RSUD Haji Makassar. The research was conducted from July to September 2020. Data collection techniques in the form of field research, through the dissemination of questionnaires supported by interview with related parties, and literature research, by studying books, scientific articles and regulations related to the problems studied. The data analysis technique used is multiple linear regression with the help of SPSS, with five stages consist of descriptive statistical analysis, data quality testing, conducting normality test, performing multiple regression analysis, and conducting hypothetical testing.

\section{RESULT AND DISCUSSION}

Validity and reliability test used to see if the primary data collection tool (through the questionnaire) used can match the target to be targeted in the study. An item should have a correlation ( $r$ ) with the total score of each variable having a value of $<0.005$ ). Items that have a significant above 0.005 are removed, so the statement is considered dead.

Table 1. Results of Reliability Measurement

\begin{tabular}{lcl}
\hline \multicolumn{1}{c}{ Variable } & Cronbach Alpha & Description \\
\hline Work Discipline & 0,724 & Reliable \\
Leadership Style & 0,818 & Reliable \\
Training & 0,780 & Reliable \\
Employee Performance & 0,852 & Reliable \\
\hline
\end{tabular}

Table 1 above shows, statement items of work discipline variables, leadership style, training and performance are reliable. This is seen from cronbach alpha alpha which is positively worth greater than 0.6 ranges from: $0.724-0.818$. Thus research instruments can be used to examine the same data under relatively similar conditions, with a reliable probability of research results. From the results of multiple linear regression analysis using SPSS will be proven research hypothesis. The result of a double linear regression analysis is:

Table 2. Regression Test

\begin{tabular}{|c|c|c|c|c|c|}
\hline \multirow{2}{*}{ Model } & \multicolumn{2}{|c|}{$\begin{array}{c}\text { Unstandardized } \\
\text { Coefficients }\end{array}$} & \multirow{2}{*}{$\begin{array}{c}\text { Standardized } \\
\text { Coefficients } \\
\text { Bet } \\
\end{array}$} & \multirow{2}{*}{$\mathrm{t}$} & \multirow{2}{*}{ Sig. } \\
\hline & B & Std. Error & & & \\
\hline (Constant) & .065 & .340 & & 191 & .849 \\
\hline Training & .372 & .076 & .376 & 4.924 & .000 \\
\hline Work Discipline & .348 & .082 & .315 & 4.237 & .000 \\
\hline Leadership Style & .291 & .088 & .282 & 3.322 & .001 \\
\hline
\end{tabular}


Based on the table above, of the three independent variables significantly affect the performance of the coefficient obtained regression equations as follows:

$$
\mathrm{Y}=0,065+0,348 \mathrm{X}_{1}+0,291 \mathrm{X}_{2}+0,372 \mathrm{X}_{3}
$$

The work discipline variable regression coefficient is 0.348 assuming that if the work discipline variable rises by one point, it is predictable that the performance variable rises by 0.348 . The leadership style variable regression coefficient is 0.291 assuming that if the leader-style variable rises by one point, it can be predicted that the performance variable will go up by 0.291 . Training Coefficient 0.372 assuming that if the training variable rises by one point, it can be predicted that performance will increase by 0.372 . this can be seen from the beta coefficient value of the training variable of 0.376 , followed by the work discipline with a beta coefisie value of 0.315 and the leadership style with a coefficient beta value of 0.282 .

Statistical tests are conducted to see if work discipline, leadership style, and training variables have a partial effect on employee performance. The criteria used to see the effect of work discipline variables, leadership styles and training partially on employee performance is to look at the probability value (p-value) in the Cofficients table (attachment). From the calculation result with SPSS it is noticeable that the $t$ value is as follows:

Table 3. Multiple Linear Regression Equations

\begin{tabular}{cccl}
\hline Variable & $\mathrm{T}$ & Sig Value & Description \\
\hline $\mathrm{X} 1$ & 4.237 & 0,000 & Significant \\
$\mathrm{X} 2$ & 3.322 & 0,001 & Significant \\
X3 & 4.924 & 0,000 & Significant \\
\hline
\end{tabular}

From the calculation result using SPSS obtained thitung amounted to 4,924 with a probability ( $\mathrm{p}$ value) of 0,000 . The probability value is smaller than alpa (5\%). It can be concluded that training has a positive effect on employee performance. This means that research hypotheses that suggest there is a positive effect of training on employee performance are significantly.

Table 3. Multiple Linear Regression Equations

\begin{tabular}{llccc}
\hline Model & $\mathrm{R}$ & $\mathrm{R}$ Square & Adjusted R Square & $\begin{array}{l}\text { Std Error of } \\
\text { the estimate }\end{array}$ \\
\hline 1 & $.778^{\mathrm{a}}$ & .605 & .593 & .26946 \\
\hline
\end{tabular}

Thus, it can be concluded that work discipline has a positive effect on employee performance. This means that the hypothesis that there is a positive influence of work discipline on employee performance is significantly proven. there is a positive influence of leadership style on employee performance is significantly proven. It can be concluded that training has a positive effect on employee performance. This 
means that research hypotheses that suggest there is a positive effect of training on employee performance are significantly.

Based on the results of the research can be known that there is a significant influence of work discipline on the performance of employees of RSUD Haji Makassar. With the proven hypothesis, there is an improvement in the performance of employees if in RSUD Haji Makassar there is justice in the provision of punitive sanctions, firmness in implementing existing rules, and the example of good leadership. The findings of this study are supported by the results of Kencanawati (2013) which said there was a significant contribution between work discipline and employee performance. This finding was also supported by the research of Wijaya \& Soedarmadi. (2013) who said work discipline has a significant influence on employee performance in a positive direction, meaning that if the work discipline improves, then employee performance will also improve. The higher awareness of its duties and responsibilities and the more obedient to regulations or discipline it is expected to foster the spirit of work and passion of work, thus creating better performance. In order to create harmonious conditions must first be realized harmony between the obligations and the rights of employees. This proves that work discipline has an influence on the performance of employees of RSUD Haji Makassar .

The results of the study proved that leadership style has a significant influence on the performance of employees of RSUD Haji Makassar. This is because the style of a leader influences the way his subordinates do the work. The leader must adjust to his subordinate's staff in order to improve the performance of his subordinates. The role of the leadership is seen as important to the progress of RSUD Haji Makassar in its efforts to improve the performance of its employees. One's leadership style will greatly affect the decision-making and performance of the hospital it leads. The findings of this study are supported by the research results of Wijaya \& Soedarmadi. (2013) which stated that leadership style has a positive effect on employee performance. Leadership style affects the performance of hospital employees. This condition occurs due to the role of leaders as top managers, which serves in moving and empowering employees. Good leadership will make employees feel happy and calm in working, so as to improve their performance well. Thus the existence of a leader has dual legitimacy because it is elected and struck a pattern of democratic leadership while having charisma in the presence of its subordinates. Other opinions also state that a good leader is a leader who can apply various types of leaders above according to the conditions and situations.

Training has an influence on the performance of employees of RSUD Haji Makassar. The findings of this study are supported by the results of research conducted by Wijaya \& Soedarmadi. (2013) which revealed a significant contribution between training and employee performance. The findings are also supported by Khairul Akhitr Lubis 's research (2008) which revealed that training has a significant influence on employee performance in a positive direction, meaning that if training 
improves, then employee performance will improve. With the training, it is expected that employees of RSUD Haji Makassar can improve skills or skills and knowledge that support the implementation of the work. This proves that employee training has a positive and significant influence on employee performance. Good training should be helped by the work, can also improve their work performance. Training for employees is a process of teaching certain knowledge and skills and attitudes so that employees are more skilled and able to carry out their responsibilities properly.

The findings of this study are supported by the research results of Wijaya \& Soedarmadi. (2013) who said there was a significant contribution between training and employee performance. This research is also supported by the results of Khairul Akhitr Lubis's research (2008) which revealed that training has a significant influence on employee performance in a positive direction, meaning that if the training gets better, then employee performance will improve. Training is an activity with the intention of improving and developing the attitude, behavior, skills, and knowledge of the employees according to the wishes of RSUD Haji Makassar. If the employee has been trained, then they will have better skills and skills, so that they are able to work more effectively and efficiently, and finally the employee gets a good job assessment as well. Employee training is an activity to improve its work ability in understanding a practical knowledge and its application in order to improve the skills, skills and attitudes required by the organization in achieving goals that are also tailored to the demands of the work that a hospital employee will have. Human resource development through training is an effort to improve the quality of human resources. Training is very important that can be done by RSUD Haji Makassar so that its employees can have and improve knowledge, ability, and skills according to the needs of the organization in the present and future

\section{CONCLUSION}

The discipline of work is positive and significant to the performance of makassar hospital employees. With work discipline, the higher the responsibility and integrity of employees in work. Leadership style has a significant effect on the performance of employees of RSUD Haji Makassar. With a good leadership style can set an example to employees, while also improving the authoritativeness of its leadership. Training has a positive and significant effect on the performance of hospital employees. With good training the quality of employees will increase which in turn increases the employees performance. Training is variable has the most dominant influence on the performance of employees of RSUD Haji Makassar.

This research have some implications. the results of this study show that work discipline, leadership style and training affect the performance of hospital employees. This has implications for the future of the hospital to pay more attention and improve the discipline of work, leadership style and coaching of employees so as to impact the improvement of employee performance. 


\section{REFERENCES}

Aritonang. (2010). Employment Compensation, Work Discipline, Human Resources Management. Mount Agung.

As'ad, M. (2010). Industrial Psychology Human Resources Science Series (IV). Liberty. Buhler, P. (2010). Alpha Teach Yourself, Management Skills. Prenada Media Group.

Dessler, G. (2011). Human Resources Management. Indices.

Dwiyanto, A. P. R. (2014). Public Service and Customer Satisfaction. PT. Alumni.

Hasibuan, M. S. P. (2002). Human Resources Management. Earth Scripts.

Kartini, K. (2011). Leader and Leadership. PT. Raja Grafindo Persada.

Kencanawati, A. A. A. M. (2013). The influence of leadership, work ethic, motivation, and discipline on the performance of employees of Denpasar Municipal Tax Service Office.

Kotler, P., \& Armstrong, G. (2012). Prinsip-Prinsip Pemasaran (13th ed.). Erlangga.

Luthans, F. (2011). Organizational Behavior. Andi.

Mangkunegara, A. P. (2013). Human Resources Management Company. PT. Rosdakarya Teen.

Mathis, R. L., \& Jackson, J. H. (2011). Human Resource Management (10th ed.). Salemba Empat.

Nimpuno, G. A. (2015). The influence of work discipline and leadership style on ud employee performance. Yogyakarta Student Library.

Nitisemito. (2013). Personnel Management (2nd ed.). Ghalia Indonesia.

Rorimpanday, L. (2013). Trasformasional, transactional, Situational, Service and Authentic Leadership Style towards the Performance of Village Employees in Bunaken District of Manado City. Journal of EMBA, 1(4), 2233-2244.

Sastrohadiwiryo. (2013). Human Resources Management. PT. Bumi Aksara.

Simamora, H. (2013). Human Resources Management (3rd ed.). Publishing Section of YKPN College of Economics.

Sinambela, L. P., \& Al., E. (2012). Employee Performance Measurement Theory and Implications. Graha Ilmu.

Suyanto. (2013). Multimedia Tools to Increase Competitive Advantage. PT. Elex Media Komputindo.

Tampubolon. (2013). Human Resources Management (1st ed.). Partner Media Discourse. Thaif, I. (2015). Effect of Training, Compensation and Work Discipline against Employee Job Performance (Studies in the Office of PT. PLN (Persero) Service Area and Network Malang). Review of European Studies, 7(11).

Wibowo, I., \& Saputra, W. (2017). The influence of leadership style on employee performance through discipline and motivation of ppsu employees duren sawit village east jakarta. Krisnadwipaya Business Management Journal, 5(2).

Wijaya, B. ganda., \& Soedarmadi. (2013). The Influence of Leadership Style, Motivation, Training and Work Discipline on Employee Performance of PT. .12 miles away.

Yukl, G. (2015). Leadership In Organization. Indices. 
